\title{
Nutritional Variation in Escherichia coli
}

\author{
By D. K. OLUKOYA $\dagger$ \\ Department of Microbiology, University of Reading, London Road, Reading RG1 5AQ, UK
}

(Received 5 March 1986)

Nutritional tests were carried out on 62 strains of Escherichia coli as part of a study on the genetic basis of natural nutritional variation. The ability of these strains to utilize 84 compounds as carbon, nitrogen and carbon plus nitrogen sources was tested using an auxanographic method. The tests revealed polymorphic characters which are suitable for genetic analysis. Very few of these strains grew on the amino acids classified as 'essential' for humans.

\section{INTRODUCTION}

Escherichia coli is normally found in the gut of warm-blooded animals, in some insects, in soil, in water near sewage outfalls and in other places contaminated by the faeces of man and other animals (Cooke, 1974; Cruikshank et al., 1973).

Considerable variation occurs in E. coli and other members of the family Enterobacteriaceae. Many techniques have been used to detect genetically determined variation in $E$. coli and other bacteria. These allow criteria to be established for classifying and identifying strains in epidemiological, ecological and genetical research, e.g. biotyping (Crichton \& Old, 1979, 1982), serotyping (Eveland et al., 1971) and sequencing certain regions of the genome (Milkman \& Crawford, 1983). The genetic basis of natural variation in $E$. coli and other members of the Enterobacteriaceae has been studied by H. P. Charles and co-workers. As a first stage in this investigation, characters were chosen for which $E$. coli $\mathrm{K} 12$ is negative and for which some wild strains are positive. Tests were then made to determine whether the genes coding for these characters are chromosomally located in $E$. coli. For ease of selection in genetic crosses, the characters of first choice were those concerned with the utilization of carbohydrates. So far, utilization of sucrose (Alaeddinoglu \& Charles, 1979; Hill, 1980), L-sorbose (Woodward \& Charles, 1982; Olukoya, 1984), and ribitol, D-arabitol and galactitol (Woodward \& Charles, 1983) have been studied. Cloning of the genes encoding these characters was undertaken (Olukoya, 1984).

This report describes nutritional tests of $62 \mathrm{E}$. coli strains. The nutrition of the strains was examined to further our studies on polymorphism in $E$. coli and in particular to provide more polymorphic characters suitable for genetic analysis.

\section{METHODS}

Organisms. Except for laboratory strains (Table 1), these were isolated from the River Kennet, UK (Woodward $\&$ Charles, 1982). E. coli strains were identified on the basis of bacteriological and biochemical tests. Each isolate was Gram negative, methyl red positive, Voges-Proskauer negative, citrate negative, $\mathrm{KCN}$ negative, lactose positive, indole positive, $\mathrm{H}_{2} \mathrm{~S}$ negative and Eijkman positive.

Media. Minimal medium was Mineral Base E of Owens \& Keddie (1969). Glucose is normally added to the medium at a concentration of $0 \cdot 2 \%(\mathrm{w} / \mathrm{v})$. Compounds to be tested as carbon and energy sources were substituted for glucose in minimal medium. Compounds to be tested as nitrogen sources were substituted for the nitrogen source in Mineral Base E.

† Present address: National Institute for Medical Research, Edmond Crescent (off City Way), PMB 2013, Yaba, Lagos, Nigeria. 
Table 1. Laboratory strains of E. coli used

Strain

B

C

K 12 strains

$\mathrm{K} 12(\lambda)$

KG 1673

AB1621

P801

KL208
Genotype

$\mathrm{F}^{-}$prototroph

$\mathrm{F}^{-}$prototroph

$\mathrm{F}^{-}$prototroph

Hfr thi-1

$\mathrm{F}^{-}$ara lac tsx gal $x y l \mathrm{mtl}$ glpD thiA $\}$

Hfr lacYl lac Y40 xyl-7 mil-2 ara-4l\}

Hfr relAl
Source or reference

Reiner (1975)

Departmental collection

Woodward \& Charles (1982)

B. Bachmann, E. coli Genetic Stock Center, Yale University

Chemicals. All chemicals used were supplied by Sigma.

Growth on compounds as carbon, nitrogen and carbon plus nitrogen source. Fifty-five wild strains and seven laboratory strains (including $\mathrm{K} 12, \mathrm{~B}$ and $\mathrm{C}$ ) of $E$. coli were tested by an auxanographic method for the ability to use 84 compounds as carbon, nitrogen or carbon plus nitrogen sources. This is a convenient method when there are many compounds to be tested (Gutnick et al., 1969; Parke \& Ornston, 1984). Cultures were grown in nutrient broth to late exponential phase. The bacteria were washed and resuspended in minimal medium. After $4-6 \mathrm{~h}$, bacteria were seeded into minimal agar cooled to $47^{\circ} \mathrm{C}$, to give about $2 \times 10^{6}$ bacteria ml-1. Crystals, powder or single droplets of compounds to be tested were placed on the surface of solidified agar and growth was recorded after $7 \mathrm{~d}$ incubation at $37^{\circ} \mathrm{C}$. Four compounds were tested per plate. Since the compounds diffuse from the original point of deposition, a concentration gradient is established which permits growth even if certain concentrations are inhibitory. As a control, the same compounds were placed on similar plates lacking bacteria. Seeded plates with no substances spotted served as second controls. A zone of growth around the point of substrate application was scored as positive. Separate colonies around the point of substrate application showed that the strain mutated to use the substrate and such responses were scored as mutable. The absence of any visible response was scored as negative. When a growth response was for any reason uncertain, the strain and substance were retested.

\section{RESULTS AND DISCUSSION}

A summary of the results for growth on compounds as carbon, nitrogen and carbon plus nitrogen sources is shown in Tables 2 and 3. A table containing the individual results for the seven laboratory strains used has been deposited with the British Library Lending Division, Boston Spa, Yorkshire LS23 7BQM, UK, as Supplementary Publication no. SUP 28022 (5 pages). In comparison with organisms such as Pseudomonas which degrade a wide variety of substrates as carbon or nitrogen sources (Stanier et al., 1966), E. coli is somewhat limited in the range of compounds it utilizes. Aromatic rings and large molecules were not degraded by the strains tested. About half of the naturally occurring amino acids were used as carbon sources. Some of the sugar and sugar derivatives were utilized. With few exceptions, most of the compounds that served as poor carbon sources were also poor nitrogen sources. The extent of nutritional diversity is illustrated by the fact that no two strains behaved in exactly the same way. No substances except glucose and glucosamine were used by every strain, and no strain used every substance.

Most of the utilizable substances were naturally occurring compounds. Few strains grew or mutated to grow on unnatural chemically synthesized compounds such as L-glucose and 3-O- $\beta$-Dgalactopyranosyl-D-arabinose. Concerning the strains that utilize these compounds, questions arise about the route of degradation, the origins and functions of the genes involved and whether $E$. coli is exposed to similar substances in nature.

The choice of characters for genetic analysis is limited by the requirement that the character be easily selectable in transduction and conjugation experiments, and that $E$. coli $\mathrm{K} 12$ be naturally negative for it. It is also preferable that the character should be specified by one gene or cluster: if it depends on genes dispersed about the chromosome, its transfer and analysis would be difficult. In the present tests, many characters suitable for genetic analysis were discovered, e.g. the utilization of L-cysteine, palatinose, acetylsalicylic acid and 3-O- $\beta$-D-galactopyranosyl-Darabinose as carbon sources. 
An interesting finding that emerged from these tests was that no strain grew on four of the amino acids which are largely absent from intestinal mucins (Tables 2). Another interesting

\section{Table 2. Percentages of strains of E. coli utilizing different compounds as carbon, nitrogen and} carbon plus nitrogen sources

Strains were tested by the auxanographic technique as described in Methods. In a few cases results were confirmed by streaking on minimal agar containing $0.2 \%(w / v)$ of particular compounds as carbon source or on minimal agar with the nitrogen source omitted.

\begin{tabular}{|c|c|c|c|c|}
\hline \multirow[b]{2}{*}{ Compound } & \multirow[b]{2}{*}{$\begin{array}{l}\text { Carbon } \\
\text { source }\end{array}$} & \multicolumn{2}{|c|}{ Nitrogen source } & \multirow[b]{2}{*}{$\begin{array}{c}\text { Carbon }+ \\
\text { nitrogen } \\
\text { source }\end{array}$} \\
\hline & & $\begin{array}{l}\text { Carbon } \\
\text { source } \\
\text { glucose }\end{array}$ & $\begin{array}{l}\text { Carbon } \\
\text { source } \\
\text { lactate }\end{array}$ & \\
\hline L-Alanine* & 97 & 98 & 100 & 93 \\
\hline L-Arginine* & 98 & 98 & 100 & 100 \\
\hline L-Asparagine & 93 & 100 & 100 & 90 \\
\hline L-Aspartate* & 89 & 100 & 100 & 97 \\
\hline L-Cysteine* & 6.5 & 97 & 100 & 28 \\
\hline L-Cystine & 2 & 16 & 85 & 3 \\
\hline L-Glutamate* & 86 & 95 & 95 & 28 \\
\hline L-Glutamine & 90 & 97 & 95 & 54 \\
\hline Glycine* & 75 & 95 & 95 & 3 \\
\hline L-Histidine† & 18 & 20 & 20 & 18 \\
\hline L-Homoserine & 13 & 89 & 92 & 8 \\
\hline L-Isoleucine $†$ & 0 & 3 & 10 & 0 \\
\hline L-Leucine $\dagger$ & 0 & 16 & 61 & 0 \\
\hline L-Lysine ${ }^{*} \dagger$ & 2 & 8 & 75 & 0 \\
\hline L-Methionine $†$ & 0 & 8 & 47.5 & 0 \\
\hline L-Phenylalanine $\dagger$ & 0 & 8 & 15 & 3 \\
\hline L-Proline* & 93 & 39 & 95 & 65.5 \\
\hline L-Serine* & 97 & 95 & 97 & 26 \\
\hline L-Threonine ${ }^{*} \dagger$ & 72 & 8 & 13.5 & 8 \\
\hline L-Tryptophan $\dagger$ & 20 & 8 & 79 & 46 \\
\hline L-Tyrosine & 5 & 77 & 93 & 15 \\
\hline L-Valine $\uparrow$ & 0 & 20 & 18 & 3 \\
\hline L-Ornithine & 6.5 & 39 & 97 & 2 \\
\hline Thiamin & 0 & 0 & 0 & 0 \\
\hline D-Glucosamine & 100 & 5 & 98 & 98 \\
\hline D-Mannosamine & 6.5 & 0 & 80 & 0 \\
\hline Uridine & 98 & 10 & 39 & 93 \\
\hline Adenosine & 90 & 97 & 95 & 95 \\
\hline Cytidine & 98 & 100 & 97 & 98 \\
\hline Guanosine & 93 & 12 & 12 & 70 \\
\hline Thymidine & 93 & 6.5 & 13 & 95 \\
\hline Inosine & 93 & 8 & $11 \cdot 5$ & 90 \\
\hline Glycoprotein & 0 & 2 & 0 & 0 \\
\hline$N$-Acetylneuraminic acid & 77 & 87 & 79 & 82 \\
\hline Mucin (porcine) & 13 & 100 & 98 & 0 \\
\hline Adenine & 0 & 90 & 9 & 0 \\
\hline Guanine & 0 & 37 & 8 & 0 \\
\hline Hypoxanthine & 0 & 36 & 6.5 & 0 \\
\hline Thymine & 0 & 34 & 8 & 0 \\
\hline Cytosine & 0 & 36 & 12 & 0 \\
\hline Taurocholic acid & 0 & 0 & 0 & 0 \\
\hline Glycocholic acid & 0 & 0 & 0 & 0 \\
\hline $\mathrm{N}$-Acetylgalactosamine & 62 & 5 & 77 & 67 \\
\hline Taurine & 0 & 0 & 6.5 & 0 \\
\hline Caffeine & 3 & 0 & 0 & 0 \\
\hline$N$-Acetyl-D-glucosamine & 100 & 5 & 100 & 98 \\
\hline
\end{tabular}


Table 3. Percentages of strains of E. coli utilizing different compounds as carbon sources

\section{Compound}

See Table 2 for details.

$\quad$ Compound
3-O- $\beta$-D-Galactopyranosyl-D-arabinose
$N$-Acetyl- $\beta$-D-glucosamine naphthol
Muramic acid (2-amino-3-O-(1-carboxyethyl)-2-deoxy-D-
Palatinose
Glucoheptonic acid (D-glycero-D-guloheptonic acid)
D-Glucoheptose
Acetylsalicylic acid
D-Fucose
L-Fucose
Vitamin A
Vitamin C
2-Deoxy-D-glucose
6-Deoxy-D-glucose
2-Deoxy-D-galactose
D-Arabinose
L-Mannose
Glucosaminic acid (2-amino-2-deoxy-D-gluconic acid)
L-Glucose
L-Fucosylamine

* Mutable response

\begin{tabular}{clc}
$\%$ & \multicolumn{1}{c}{ Compound } & $\%$ \\
$29 \cdot 5^{*}$ & D-Mannoheptulose & 2 \\
3 & Uridine-5-diphosphoglucose & 2 \\
0 & Acetylcholine chloride & 0 \\
$11 \cdot 5$ & $N$-Acetylneuramin lactose & 0 \\
0 & Neuraminic acid $\beta$-glycoside & 0 \\
2 & D-Glucose & 100 \\
24 & D-Galactose & 98 \\
2 & D-Ribose & 90 \\
93 & L-Arabinose & 93 \\
0 & D-Mannose & 98 \\
10 & Uracil & 2 \\
0 & Salicin & 8 \\
0 & $N$-Acetyl-D-mannosamine & 74 \\
0 & Lactulose & $93^{*}$ \\
26 & Caffeic acid & 0 \\
52 & D-Glucuronic acid & $88 \cdot 5$ \\
$5^{*}$ & Chlorogenic acid & 0 \\
2 & Starch (potato) & 0 \\
44 & L-Sorbose & 26
\end{tabular}

point is that the amino acids on which no strains, or few, grew are those which are the 'essential' amino acids in human nutrition.

Future work will concentrate on the genetic basis of some of the variable characters discovered in this study.

\section{REFERENCES}

alaeddinoglu, N. G. \& Charles, H. P. (1979) Transfer of a gene for sucrose utilization into Escherichia coli $\mathrm{K} 12$, and consequent failure of expression of D-serine utilization. Journal of General Microbiology 110, 47-59.

BENDER, A. E. (1973). Nutrition and Dietetic Foods. New York: Leonard Hill Books.

Clamp, J. R., Allen, A., Gibbons, R. A. \& Roberts, G. P. (1978). Chemical aspects of mucus. British Medical Bulletin 34, 25-41.

COOKE, M. E. (1974). Escherichia coli and Man. Edinburgh: Churchill Livingstone.

Crichton, P. B. \& OLD, D. C. (1979). Biotyping of Escherichia coli. Journal of Medical Microbiology 12, 473-486.

CRICHTON, P. B. \& OLD, D. C. (1982). A biotyping scheme for the subspecific discrimination of Escherichia coli. Journal of Medical Microbiology 15, 233242.

Crim, M. C. \& Munro, H. N. (1976). Protein. In Present Knowledge in Nutrition, 4th edn, pp. 43-54. New York \& Washington: Nutrition Foundation.

Cruickshank, R., Duguid, J. P., Marmion, B. P. \& Swain, R. H. A. (1973). Medical Microbiology, vol. 1, 12th edn. London \& New York: Longman.

Eveland, W. C., Oliver, W. J. \& Neel, J. V. (1971). Characteristics of Escherichia coli serotypes in the Yanomana, a primitive Indian tribe of South America. Infection and Immunity 4, 753-756.

Gutnick, D., Calvo, M. J., Klopotowski, T. \& AMEs, B. N. (1969). Compounds which serve as the sole source of carbon or nitrogen for Salmonella typhimurium LT2. Journal of Bacteriology 100, 215219.

HILL, S. H. (1980). Genetic analysis of variation in Escherichia coli. PhD thesis, University of Reading, UK.

Milkman, R. \& Crawford, I. P. (1983). Clustered third base substitutions among wild strains of Escherichia coli. Science 221, 378-379.

Olukoya, D. K. (1984). Nutritional variation and the genetics of L-sorbose utilization in Escherichia coli. $\mathrm{PhD}$ thesis, University of Reading, UK.

OWENs, J. D. \& KeDDIE, R. M. (1969). The nitrogen nutrition of soil and herbage coryneform bacteria. Journal of Applied Bacteriology 32, 338-347.

Parke, D. \& Ornston, L. N. (1984). Nutritional diversity of Rhizobiaceae revealed by auxanography. Journal of General Microbiology 130, 1743-1750.

REINER, A. M. (1975). Genes for ribitol and D-arabitol catabolism in Escherichia coli: their loci in C strains and absence in K-12 and B strains. Journal of Bacteriology 123, 530-536.

Stanier, R. Y., Palleroni, N. J. \& Doudoroff, M. (1966). The aerobic pseudomonads: a taxonomic study. Journal of General Microbiology 43, 159-271.

WoodWARD, M. J. \& Charles, H. P. (1982). Genes for L-sorbose utilization. Journal of General Microbiology 128, 1969-1980.

Woodward, M. J. \& Charles, H. P. (1983). Polymorphism in Escherichia coli: rtl atl and gat regions behave as chromosomal alternatives. Journal of General Microbiology 129, 75-84. 